\title{
ОРГАНИЧЕСКАЯ ГЕОХИМИЯ КАЙНОЗОЙСКИХ ПОРОД УШУМУНСКОГО БУРОУГОЛЬНОГО МЕСТОРОЖДЕНИЯ СРЕДНЕАМУРСКОГО ОСАДОЧНОГО БАССЕЙНА
}

\author{
Тимошина Ирина Дмитриевна 1 , \\ TimoshinalD@ipgg.sbras.ru
}

\author{
Фомин Александр Николаевич1,2, \\ FominAN@ipgg.sbras.ru, a.fomin@g.nsu.ru \\ 1 Институт нефтегазовой геологии и геофизики СО РАН, \\ Россия, 630090, г. Новосибирск, пр. Ак. Коптюга, 3. \\ 2 Новосибирский Государственный Университет, \\ Россия, 630090, г. Новосибирск, ул. Пирогова, 1.
}

\begin{abstract}
Актуальность исследования обусловлена необходимостью расширения российской ресурсной базы Дальнего Востока. Изучение осадочных бассейнов и их углеводородного потенциала, разработка новых технологий прогноза традиционных и нетрадиционных месторождений углеводородного сырья остается приоритетным направлением Российской АН на многие годы. Оиенка обогащенности пород органическим веществом и его генерационного потенциала поможет в работах по бассейновому моделированию. Настоящие исследования нужны также для: уточнения обстановок накопления органического вещества; реконструкции ландшафотов и биологического мира в кайнозое.

Цель: охарактеризовать биологический источник органического вещества, условия его накопления, обстановки диагенеза и уровень катагенетической зрелости в породах Ушумунского буроугольного месторождения.

объекты: угли, глины и алевриты Ушумунского буроугольного месторождения Среднеамурского осадочного бассейна.

Методы: сопоставление данных пиролиза и изотопного анализа органического вещества и характеристик углеводородовбиомаркеров, полученных с помощью хромато-масс-спектрометрии в насыщенной и ароматической фракциях битумоидов, оценка источников, диагенетических обстановок и катагенетической преобразованности органического вещества.

Результаты. Породы палеогена и неогена Ушумунского буроугольного месторождения Среднеамурского осадочного бассейна впервые изучены методами органической геохимии. Органическое вещество исследованных образцов имеет признаки как террагенного (гумусового), так и аквагенного (сапропелевого) типов. Изотопный состав углерода органического вещества, распределение н-алканов, наличие каурана, биерана, филлокладанов (биомаркеров высших растений Podocarpaceae u Araucareaceae) в насыщенной фрракции битумоидов, ретена (биомаркера хвойных растений) в ароматической фракции свидетельствуют о террагенной природе органического вещества. Вместе с тем в большинстве образцов характеристики ароматической фрракции соответствуют аквагенному органическому веществу: низкие концентрации фенантренов, высокие моно- и триароматических стероидов, распределение метилдибензотиофеенов, вероятное присутствие длинноиепочечных алкилнафрталинов - биомаркеров озерных водорослей Botryococcus braunii. Также в большинстве образцов концентрации фитана значительно выше, чем пристана, и половина образцов согласно водородному индексу Нl относится к типу II (аквагенный морской). Морских отложений в районе исследований нет, по-видимому, тип II является смесью типов I (аквагенный озерный) III (континетальный). Причем, судя по изменениям HI по разрезу, режим осадконакопления менялся неоднократно с озерного до торфяно-болотного и обратно. В ряде образцов максимумы в составе ациклических изопреноидов приходятся на i- $\mathrm{C}_{21}$ и і-С 22, возможно, из-за значительного вклада организмов домена археа в исходное живое вещество. Согласно высоким концентрациям дибензотиофренов, органическое вещество пережило диагенез с избытком серы в осадке. Вероятно, двойственность признаков (террагенные и аквагенные) связана со специфичностью исходной биоты этого бассейна и является характерной для ее возрастной и/или географической локализации. Низкие значения показателей отражательной способности витринита, пиролитические характеристики, резкое преобладание соединений с нечетным числом атомов в молекуле в н-алканах, наличие биогопанов и гопенов при почти полном отсутствии типичных стеранов и терпанов, распределение триароматических стероидов соответствуют катагенетически незрелому органическому веществу, и, возможно, недостаточная зрелость усиливает эту двойственность характеристик.
\end{abstract}

\section{Ключевые слова:}

Дальний Восток, палеоген, неоген, бурые угли, пиролиз, изотопы, углеводороды-биомаркеры, генезис и катагенез органического вещества.

\section{Введение}

Ушумунское буроугольное месторождение находится в пределах одноименного прогиба на югозападе Среднеамурского осадочного бассейна и сложено болотно-озерно-аллювиальными отложениями Бирофельдского грабена, образовавшегося в процессе проявления кайнозойского рифтогенеза на тихоокеанской окраине Азии [1]. Пласты угля приурочены к терригенным толщам верхней подсвиты чернореченской свиты (олигоцен) и ушумунской свите (миоцен).
До настоящего времени эти отложения не были изучены методами органической геохимии, которые стали важными инструментами и широко используются для определения генетического типа органического вещества (OB), и даже восстановления биологических сообществ и среды обитания его источников, выяснения обстановок трансформации ОВ в диагенезе и уровня его катагенетической преобразованности. Для определения генетического типа ОВ наряду с оценкой керогена по водородному индексу (HI) пиролиза $[2,3]$ 
и обогащенностью органического углерода изотопом ${ }^{12} \mathrm{C}$ [4 и др.] используются исследования распределений углеводородов (УВ): нормальных алканов, ациклических изопреноидов, стеранов, терпанов, ароматических и серосодержащих соединений [5-10 и др.]. Можно предполагать участие в исходной биоте организмов домена археа при высоких концентрациях ациклических изопреноидов состава $>\mathrm{C}_{20}$, озерных водорослей по наличию длинноцепочечных алкилнафталинов, констатировать вклад высших растений по наличию ретена, а также каурана, биерана, филлокладанов [5 и др.]. По некоторым соединениям насыщенной и ароматической фракций битумоидов определяют литологический состав осадка в бассейне накопления OB, например, избыток диастеранов указывает на глинистые материнские породы [5, 6 и др.], повышенное значение 4-метилдибензотиофена к фенантрену - на кремнистые [11]. При высоких концентрациях гомогопана $\mathrm{C}_{35}$ и дибензотиофенов делают заключение о сероводородном заражении осадка в диагенезе [5-7, 12, 13 и др.]. В дополнение к определению катагенетической преобразованности ОВ посредством углепетрографических и пиролитических исследований, которые иногда не применимы (например, при отсутствии мацералов и при насыщенности толщ битумами) используют многочисленные углеводородные показатели: отношения стеранов, гомогопанов, соединений ароматической фракции [510 и др.]; обилие биогопанов и гопенов, присутствие каурана, биерана, филлокладанов при отсутствии стеранов и терпанов, характерные также для OB, катагенетически не преобразованного или слабо преобразованного [6, 14-18 и др.].

Для расширения российской ресурсной базы Дальнего Востока необходимы работы по бассейновому моделированию, в котором используются данные по обогащенности пород $\mathrm{OB}$, оценка его катагенетической преобразованности и генерационного потенциала - не реализованных способностей ОВ производить УВ, а также концентрации автохтонных и аллохтонных битумоидов. В научном плане исследования ОВ нужны для уточнения обстановок накопления органического вещества, для реконструкции ландшафтов и биологического мира в кайнозое. Цель настоящей работы - уточнить степень обогащенности пород ОВ, его генетический тип и состав исходной биоты, диагенетические обстановки преобразования и уровень катагенетических изменений ОВ угленосной толщи Ушумунского месторождения.

\section{Объект и методы исследований}

На переданной В.В. Крапивенцевой для изучения в лабораторию органической геохимии ИНГГ СО РАН коллекции образцов верхней части верхней подсвиты чернореченской (Р ${ }_{3}^{1-2}$ с̌r) свиты (залежи III и IV), бирофельдской $\left(\mathrm{P}_{3}{ }^{2} \mathrm{bf}\right)$ свиты (кровля залежи III) и ушумунской $\left(\mathrm{N}_{1}{ }^{1}\right.$ uš) свиты (залежь II) из скв. 1138, 1157 и 1180 Ушумунского месторождения (табл. 1) проведены следующие геохимические исследования: определены содержания органического углерода $\left(\mathrm{C}_{\text {орг }}\right)$ в породах [19], его изотопный состав по методике $[20,21]$, пиролитические характеристики $[2,3]$ и уровень зрелости органического вещества. В этих же пробах проведена экстракция битумоидов хлороформом и определение их группового состава по традиционным методикам [19], состав УВ насыщенных фракций методом газожидкостной хроматографии [22], состав соединений насыщенной и ароматических фракций методом хромато-масс-спектрометрии [22]. В процессе настоящих исследований выяснены условия формирования, тип и уровень катагенетической преобразованности ОВ глин, алевритов и углей Ушумунского месторождения. Результаты были частично доложены на конференциях [23, 24].

Таблица 1. Положение и состав изученных образцов в разрезе Уиумунского буроугольного месторождения Среднеамурского осадочного бассейна

Table 1. Position and composition of the studied samples in the section of the Ushumunskoe brown coal field of the Middle Amur sedimentary basin

\begin{tabular}{|c|c|c|c|c|c|}
\hline 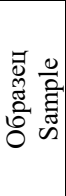 & 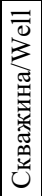 & 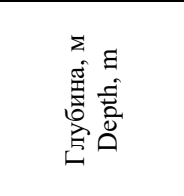 & 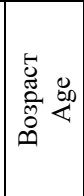 & 㞼 & 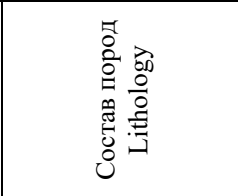 \\
\hline 1 & \multirow{5}{*}{$\stackrel{\infty}{=}$} & $\begin{array}{l}96,60-96,70 \\
\end{array}$ & \multirow{3}{*}{$\mathrm{N}_{1}{ }^{1} \mathrm{us}$} & \multirow{3}{*}{$\begin{array}{c}\text { ушумунская } \\
\text { ushumun }\end{array}$} & \multirow{5}{*}{$\begin{array}{l}\text { глина углистая } \\
\text { carbonaceous clay }\end{array}$} \\
\hline 2 & & $121,40-121,50$ & & & \\
\hline 3 & & $122,80-123,08$ & & & \\
\hline 4 & & $132,10-132,40$ & \multirow{5}{*}{$\mathrm{P}_{3}{ }^{2} \mathrm{bf}$} & \multirow{5}{*}{$\begin{array}{c}\text { бирофельд- } \\
\text { ская } \\
\text { birofeld }\end{array}$} & \\
\hline 5 & & $133,70-134,50$ & & & \\
\hline 6 & \multirow{2}{*}{$\stackrel{n}{=}$} & $63,75-63,90$ & & & \multirow{2}{*}{ глина/clay } \\
\hline 7 & & $65,00-67,00$ & & & \\
\hline 8 & & $101,35-101,40$ & & & $\begin{array}{c}\text { глина углистая } \\
\text { carbonaceous clay }\end{array}$ \\
\hline 9 & & $102,50-102,70$ & \multirow{7}{*}{$\mathrm{P}_{3}^{2}$ čr } & \multirow{11}{*}{$\begin{array}{c}\text { черноречен- } \\
\text { ская } \\
\text { black River }\end{array}$} & $\begin{array}{c}\text { бурый уголь } \\
\text { brown coal }\end{array}$ \\
\hline 10 & & $105,90-106,20$ & & & алеврит глинистый \\
\hline 11 & & $111,80-112,00$ & & & \\
\hline 12 & & $112,00-112,25$ & & & \\
\hline 13 & $\circ$ & $116,02-116,12$ & & & Глина углистая \\
\hline 14 & $\Xi$ & \begin{tabular}{|l|}
$117,30-117,40$ \\
\end{tabular} & & & \\
\hline 15 & & $117,80-118,00$ & & & глина/clay \\
\hline 16 & & $162,20-162,40$ & \multirow{4}{*}{$\mathrm{P}_{3}{ }_{3}^{\mathrm{cr} r}$} & & $\begin{array}{c}\text { глина углистая } \\
\text { carbonaceous clay }\end{array}$ \\
\hline 17 & & $164,70-164,75$ & & & \begin{tabular}{|c} 
бурый уголь/brown \\
coal
\end{tabular} \\
\hline 18 & & $164,75-164,80$ & & & $\begin{array}{c}\text { глина углистая } \\
\text { carbonaceous clay }\end{array}$ \\
\hline 19 & & $165,80-165,90$ & & & алеврит/silt \\
\hline
\end{tabular}

\section{Геохимия органического вещества} Ушумунского месторождения

Все изученные толщи обогащены рассеянным $\mathrm{OB}-\mathrm{C}_{\text {орг }}$ составляет от 0,8-7,1\% в алевритах до 1,5-23,0 \% в глинистых породах (табл. 2), причем рассеянным ОВ наиболее обогащены ушумунские глины (11,7-23,0 \%). Согласно изотопному составу углерода органическое вещество является террагенным - $\left(\delta^{13} \mathrm{C} \geq 27 \%\right.$ табл. 2, рис. 1, Б) [4]. Повышенная обогащенность ОВ, судя по прямо пропорциональной зависимости его изотопного состава $\delta^{13} \mathrm{C}$ (рис. 2) от концентраций $\mathrm{C}_{\text {орг }}$, 
связана именно с вкладом террагенного керогена типа III (рис. 2). Две исследованные пробы угля чернореченской свиты находятся на рисунке вне общего тренда повышения $\delta^{13} \mathrm{C}$ с ростом концентрации $\mathrm{C}_{\text {орг }}$, но их изотопный состав не опровергает общую закономерность.

По данным пиролиза более половины образцов также относится к керогену типа III (HI $\leq 160$ мг $\left.\mathrm{УB} / г \mathrm{C}_{\text {орг }}\right)[2,3,25]$, среди них все глины бирофельдской свиты, все алевриты и три пробы глины чернореченской свиты (табл. 2, рис. 1, А, 2). Судя по высо- кому водородному индексу НI, кероген типа II (аквагенный морской) отмечается во всех глинах ушумунской и углях чернореченской свиты. В глинах чернореченской свиты также обнаружено три стратиграфических уровня (102,50-102,70 м; 116,02-117,40 м; 164,70-164,80 м) обогащенности аквагенным ОВ (табл. 2, рис. 1, А, 2). В образцах этих трех уровней данные пиролиза (кероген типа II по НI) не соответствуют выводам по изотопному анализу углерода (террагенный кероген).

Таблица 2. Концентрации, пиролитические и изотопные характеристики органического углерода, концентрации и групповой состав битумоидов

Table 2. Concentrations, pyrolytic and isotopic characteristics of organic carbon; and concentration and group composition of bitumen extracts

\begin{tabular}{|c|c|c|c|c|c|c|c|c|c|c|c|c|}
\hline \multirow[b]{2}{*}{ 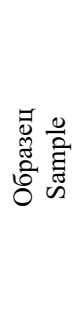 } & \multirow[b]{2}{*}{ 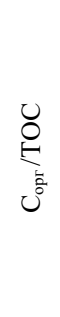 } & \multicolumn{4}{|c|}{$\begin{array}{l}\text { Пиролиз } \\
\text { Pyrolysis }\end{array}$} & \multirow[b]{2}{*}{$\delta^{13} \mathrm{C}$} & \multirow[b]{2}{*}{ 总 } & \multirow[b]{2}{*}{$\beta$} & \multicolumn{4}{|c|}{$\begin{array}{c}\text { Групповой состав, \% на } b_{\text {хл }} \\
\text { Group composition, \% per bitumen }\end{array}$} \\
\hline & & S1 & S2 & $\mathrm{T}_{\max }$ & HI & & & & 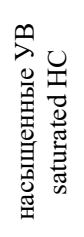 & 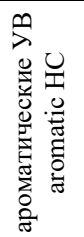 & 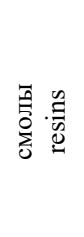 & 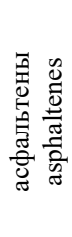 \\
\hline 1 & 17 & 2,2 & 29 & 408 & 198 & $-25,0$ & 0,71 & 2,9 & 10,2 & 4,3 & 75,4 & 10,1 \\
\hline 2 & 23 & 2,8 & 51 & 416 & 298 & $-25,1$ & 0,66 & 2,0 & 7,7 & 3,0 & 79,8 & 9,5 \\
\hline 3 & 12 & 1,4 & 22 & 373 & 231 & $-24,0$ & 0,58 & 3,5 & 8,1 & 6,3 & 70,0 & 15,6 \\
\hline 4 & 6,5 & 0,2 & 5,8 & 408 & 97 & $-25,3$ & 0,08 & 0,9 & 10,7 & 4,6 & 76,7 & 8,0 \\
\hline 5 & 5,1 & 0,2 & 3,7 & 431 & 75 & $-25,4$ & 0,06 & 0,8 & 13,4 & 7,5 & 68,6 & 10,6 \\
\hline 6 & 2,4 & 0,1 & 2,2 & 429 & 76 & $-25,8$ & 0,05 & 1,5 & 13,1 & 7,1 & 75,9 & 3,9 \\
\hline 7 & 1,5 & 0,0 & 1,0 & 425 & 46 & $-26,5$ & 0,03 & 1,3 & 16,0 & 12,7 & 68,1 & 3,1 \\
\hline 8 & 5,6 & 0,2 & 9,1 & 432 & 160 & $-26,7$ & 0,08 & 1,0 & 10,3 & 4,3 & 77,7 & 7,7 \\
\hline 9 & 56 & 4,7 & 116 & 401 & 279 & $-24,4$ & 2,25 & 2,8 & 8,1 & 4,4 & 66,0 & 21,5 \\
\hline 10 & 6,5 & 0,3 & 5,6 & 425 & 89 & $-26,1$ & 0,08 & 0,8 & 9,1 & 7,9 & 69,4 & 13,6 \\
\hline 11 & 7,1 & 0,5 & 8,1 & 424 & 114 & $-26,7$ & 0,11 & 1,0 & 12,8 & 9,0 & 72,8 & 5,4 \\
\hline 12 & 5,4 & 0,3 & 6,6 & 428 & 119 & $-25,9$ & 0,10 & 1,3 & 13,6 & 4,6 & 77,1 & 4,8 \\
\hline 13 & 10 & 1,3 & 21 & 417 & 207 & $-25,0$ & 0,31 & 2,1 & 6,9 & 1,1 & 80,4 & 11,6 \\
\hline 14 & 14 & 1,0 & 33 & 428 & 257 & $-25,7$ & 0,30 & 1,6 & 4,1 & 11,9 & 79,6 & 4,5 \\
\hline 15 & 2,8 & 0,1 & 2,7 & 424 & 87 & $-26,3$ & 0,06 & 1,5 & 14,0 & 6,7 & 74,2 & 5,1 \\
\hline 16 & 9,2 & 0,2 & 7,6 & 420 & 84 & $-24,9$ & 0,09 & 0,7 & 10,1 & 5,8 & 80,6 & 3,5 \\
\hline 17 & 52 & 3,8 & 77 & 404 & 181 & $-24,7$ & 1,55 & 2,1 & 5,9 & 4,9 & 70,3 & 18,9 \\
\hline 18 & 7,6 & 1,2 & 20 & 423 & 248 & $-25,8$ & 0,54 & 4,9 & 3,5 & 4,2 & 76,8 & 15,5 \\
\hline 19 & 0,8 & 0,0 & 0,7 & 423 & 52 & $-26,4$ & 0,03 & 2,8 & 14,8 & 20,6 & 61,1 & 3,6 \\
\hline
\end{tabular}

Примечание: $C_{\text {орг }}$ - кониентрачия органического углерода в \% на породу; S1 - количество свободных углеводородов (УВ), мг УВ/г породы; $S 2$ - количество УВ, полученных в прочессе крекинга керогена, мг УВ/г породы; НI - водородный индекс $\left(S 2 / C_{\text {орг }} \times 100\right)$, мг $У B /$ г $C_{\text {орг; }} ; T_{\max }-$ температура $\left({ }^{\circ} \mathrm{C}\right)$ максимального выхода УВ пика $S 2$ в проиессе крекинга керогена; $\delta{ }^{13} C$-изотопный состав $C_{\text {орг }} \%$; $b_{x л}-$ кониентрачия экстрагируемых хлороформом битумоидов в

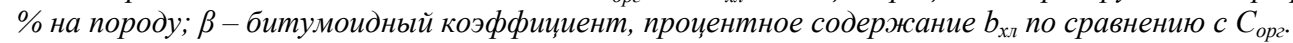

Note: TOC - total organic carbon, \% per rock; S1 - volatile hydrocarbons (HC), mg HC/ g rock; S2 - HC generated by cracking of kerogen, $\mathrm{mg} \mathrm{HC/g}$ rock; $\mathrm{HI}$ - hydrogen index (S2/TOC $\times 100), \mathrm{mg} \mathrm{HC/g} \mathrm{TOC;} T_{\text {max }}-$ the temperature $\left({ }^{\circ} \mathrm{C}\right)$ at which the maximum amount of $S 2$ is generated from the kerogen; $\delta^{13} C-T O C$ isotope composition, \%o; bitumen - organic matter extracted from rock using chloroform, \% per rock; $\beta$-bitumen ratio, the ratio of extractable bitumen to TOC, \%.

Возможно, противоречивость результатов изотопного и пиролитического анализов ОВ на его генетический тип примерно в половине образцов коллекции обусловлена специфичностью исходной биоты этого бассейна, характерной, вероятно, для ее географической локализации и/или возраста. Однако такое несоответствие отмечалось ранее и в незрелом девонском органическом веществе Кузбасса [26]. Бурые угли, изученные в работе [14] в верхней части разреза, также имеют НІ>160 мг УВ/г С орг. Следовательно, еще одной причиной подобных изотопных и пиролитических характеристик может быть низкий уровень катагенетической преобразованности ОВ. Соотношение концентраций $\mathrm{C}_{\text {орг }}$ и водородного индекса НI (рис. 2) 
присуще автохтонному ОВ, относящемуся к типу III и II, сохранившему генерационный потенциал и не содержащему битумов. От общей тенденции отклоняются два чернореченских угля, в которых высокий $\mathrm{C}_{\text {орг }}$ не сопровождается значительным повышением генерационных свойств, однако, судя по их взаимному расположению на рис. 2, обогащенность ОВ связана с вкладом террагенного керогена типа III. По- скольку морских отложений кайнозойского возраста в пределах месторождения нет, тип II, вероятно, является смесью типов I (аквагенный озерный) и III (террагенный). Во всех изученных образцах $\mathrm{OB}$ незрелое по данным пиролиза (табл. 2, рис. 1), что подтверждается результатами углепетрографии в углях - отражательная способность витринита $\mathrm{R}_{\mathrm{vt}}^{\mathrm{o}}$ составляет 0,42 и $0,43 \%$.
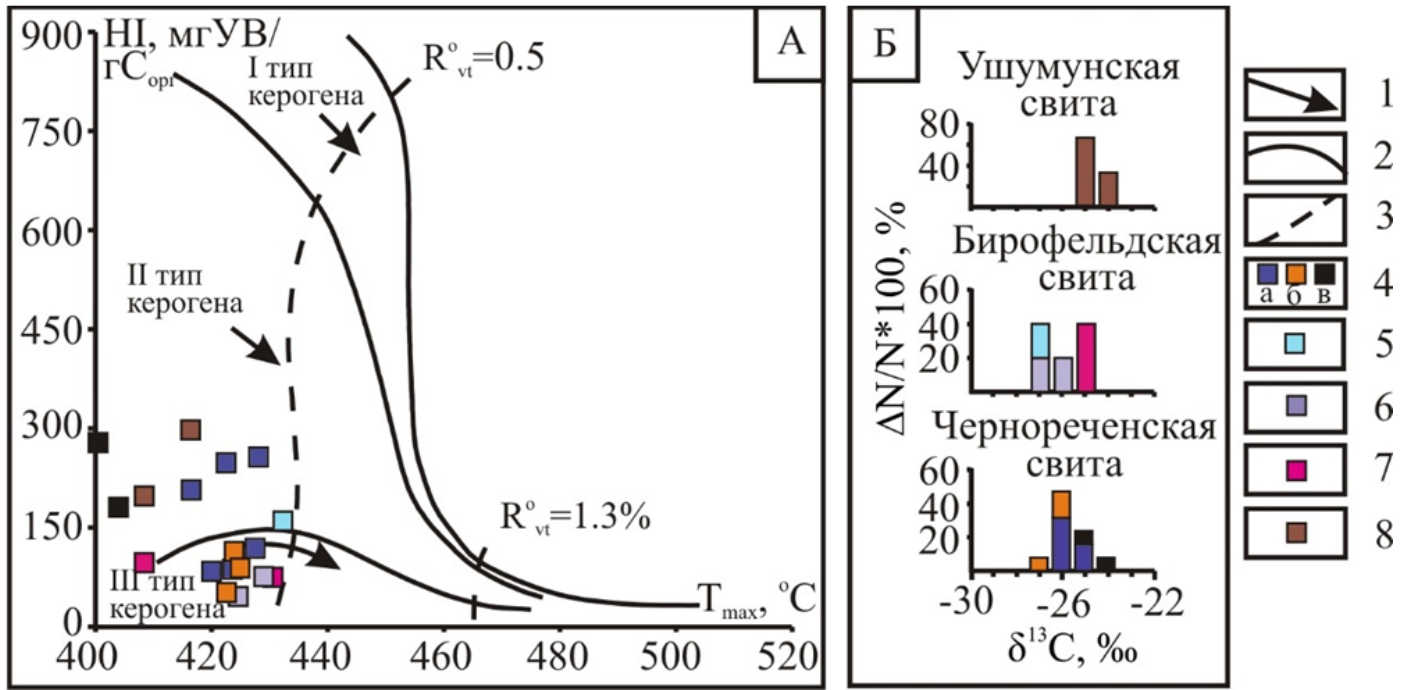

Pис. 1. Диаграмма НI-T $T_{\max }$ и изотопный состав ( $\delta^{13} \mathrm{C}$, \%о) органического веществв в образиах Уиумунского буроугольного месторождения Среднеамурского осадочного бассейна: 1 - направленность изменений величин НI и $T_{\text {max }}$ в катагенезе; 2 - линии, ограничивающие максимальные значения водородного индекса для трех типов органического вещества (I - аквагенного озерного, II - аквагенного морского, III - террагенного); 3 - изолинии отражательной способности витринита $\left(R_{v t}^{o}\right)$, ограничивающие главную зону нефтеобразования; 4 глины (а), алевриты (б) и угли (в) чернореченской свиты $\left(P_{3}{ }^{l-2} \check{c} r\right)$ скв. 1180; 5 - глина бирофельдской свить $\left(P_{3}{ }^{2} b f\right)$ скв. 1180; 6- глины бирофельдской свитыл $\left(P_{3}{ }^{2} b f\right)$ скв. 1157; 7 - глинь бирофельдской свитьл $\left(P_{3}{ }^{2} b f\right)$ скв. 1138; 8 - глины ушумунской свиты $\left(N_{l}{ }^{1} u \check{s}\right)$ скв. 1138

Fig. 1. HI- $T_{\max }$ diagram and isotopic composition $\left(\delta^{13} \mathrm{C}, \%\right.$ of organic matter in samples from the Ushumunskoe brown coal field of the Middle Amur sedimentary basin: 1 - direction of changes in hydrogen index (HI) and $T_{\max }$ during catagenesis; 2 - lines delimiting the maximum values of the HI for three types of organic matter (I - sapropelic lake, II - sapropelic marine, III - terrestrial); $3-R^{o}{ }_{v t}$ contours of the oil window; 4 - clay (a), silt (b) and coal (c) of the Black River $\mathrm{Fm}\left(P_{3}{ }^{1-2} \mathrm{cr}\right)$ in well 1180; 5 - the Birofeld Fm clay $\left(P_{3}{ }^{2} \mathrm{bf}\right)$ in well 1180; 6 - the Birofeld Fm clays $\left(P_{3}{ }^{2}\right.$ bf) in well 1157; 7 - the Birofeld Formation clays $\left(P_{3}^{2} b f\right)$ in well $1138 ; 8$ - the Ushumun Fm clays of $\left(N_{1}{ }^{1}\right.$ uš) in well 1138
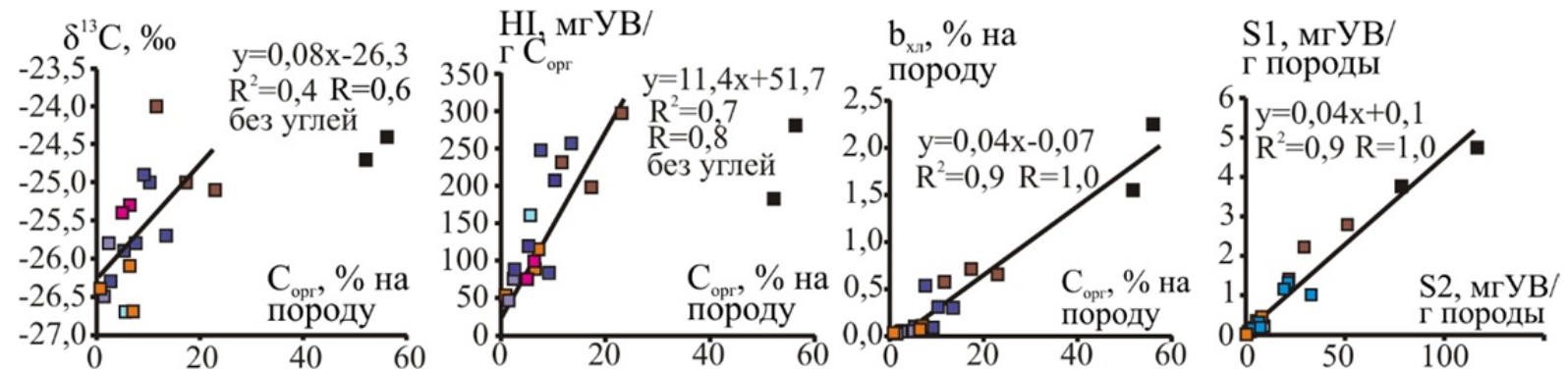

Pис. 2. Взаимосвязь между кониентрациями органического вещества $\left(C_{\text {орг }}\right)$, его изотопным составом $\left(\delta^{13} C\right)$ и водородным индексом (HI), а также с концентрациями битумоидов ( $\left.b_{x л}\right)$, соотношение $S 1$ и $S 2$ (условные обозначения на рис. 1)

Fig. 2. Relationship between concentrations of the organic matter (TOC), its isotopic composition $\left(\delta^{13} C\right)$ and hydrogen index (HI), as well as with concentrations of the bitumen extracts; relationship between S1 and S2 (legend in Fig. 1)

Наиболее обогащены битумоидами чернореченские угли, а рассеянное ОВ содержит наиболее высокий процент битумоида в ушумунских глинах, и также в среднем довольно высокие концентрации отмечаются в чернореченских глинах в интервалах, обо- гащенных керогеном с высоким НІ (табл. 2, рис. 2). Низкий битумоидный коэффициент $\beta(<5 \%)$ и соотношение концентраций $\mathrm{C}_{\text {орг }}$ и $\mathrm{b}_{\mathrm{xл}}$, а также «битумоидной» (S1) и «керогеновой» (S2) составляющих $\mathrm{OB}$ (табл. 2, рис. 2) указывают на автохтонность битумо- 
идов коллекции, следовательно, выводы по геохимическому изучению битумоидов можно распространить на вмещающие толщи. В битумоидах всех образцов преобладают смолы (61,1-80,6 \%), насыщенных УВ $<15 \%$, ароматических УВ $<10 \%$, за исключением 3 образцов $(11,9-20,6 \%)$, в двух из них и еще в одной глине содержания ароматических УВ больше, чем насыщенных, тогда как в основном насыщенных УВ примерно вдвое больше, чем ароматических, а в трех пробах глин это превышение увеличивается до 2,6-6,3 раз (табл. 2). Концентрации асфальтенов в среднем составляют 9,3\%, но варьируют широко - от $3,5 \%$ в пробе из чернореченских глин до 18,9 и 21,5 \% в зольных углях.

Распределение нормальных алканов соответствует террагенному незрелому ОВ - максимумы на $n \mathrm{C}_{29}$ и на $n \mathrm{C}_{27}, n \mathrm{C}_{27} / n \mathrm{C}_{17}>1,7$ и коэффициенты нечетности СРІ $>2$ (табл. 3 , рис. 3). Соотношение $\mu$-алканов $n \mathrm{C}_{27} / n \mathrm{C}_{31}$, по которому определяют пропорции вклада древесных и травянистых растений [27 и др.] высокое (в основном >1) и указывает на высокий процент древесных растений по сравнению с травами. Судя по соотношению $н$-алканов $\left(\mathrm{Paq}=\left(n \mathrm{C}_{23}+n \mathrm{C}_{25}\right) /\left(n \mathrm{C}_{23}+n \mathrm{C}_{25}+n \mathrm{C}_{29}+n \mathrm{C}_{31}\right)\right.$, по которому определяют характер озерных растений [27, 28 и др.], источник ОВ не был исключительно наземным - в изученной коллекции нет образцов с $\mathrm{Paq}<0,1$. В основном Paq составляет 0,2-0,4, что характерно для растений, имеющих надводную часть, а в трех образцах Раq=0,5, что свидетельствует о высоком вкладе подводных растений. Этот вывод согласуется с выводом по результатам пиролиза (стратиграфические уровни с высокими значениями НI) о периодическом возникновении озерных обстановок осадконакопления. В ациклических изопреноидах чаще фитан имеет более высокие концентрации, чем пристан, что свойственно аквагенному ОВ, и в ряде образцов с высокими концентрациями фитана присутствуют необычные максимумы на $i \mathrm{C}_{21}$ и $i \mathrm{C}_{22}$ (рис. 3). Высокие концентрации ациклических изопреноидов состава $>\mathrm{C}_{20}$ могут указывать на значительный вклад археа в исходное живое вещество [6]. Возможно, эти особенности связаны с незрелостью террагенного керогена при довольно высоких концентрациях ОВ или со специфичностью исходной биоты этого бассейна.

В циклических насыщенных биомаркерах типичные пики стеранов и терпанов отсутствуют или совершенно теряются на фоне интенсивных выходов соединений, свойственных незрелому органическому веществу. Отсутствие стеранов и терпанов или очень низкие их концентрации, наличие каурана, биерана, филлокладанов, биогопанов и гопенов (рис. 4) характерно для незрелого ОВ [14-18]. Наличие тетрациклических битерпанов, таких как биеран, кауран, филлокладаны, свидетельствует об участии в комплексе исходного живого вещества смол высших растений Podocarpaceae и Araucareaceae [5, 6, 29].

В большинстве образцов концентрация фенантренов $(<65 \%)$, моно- и триароматических стероидов ( $>3 \%)$, отношение ТАС/MАС $(>2)$ (табл. 4, рис. 5) соответствуют аквагенному ОВ [7]. ОВ, судя по низ- кому отношению 4MDBT/P, накапливалось в бассейне с глинистой седиментацией, за исключением образцов № 6, 18, 19, в которых повышенные значения 4MDBT/P указывают на кремнистые материнские породы [11]. Почти во всех образцах (рис. 5) аквагенное «V»-образное распределение метилдибензотиофенов [8-10] и почти в половине образцов высокие концентрации дибензотиофенов свидетельствуют об избытке серы в осадке в диагенезе [7, 12, 13]. Отношение триароматических стероидов ТАСИ $=\mathrm{TAC}_{20}$ ${ }_{21} /\left(\mathrm{TAC}_{20-21}+\mathrm{TAC}_{26-28}\right)$ в основном низкое $(\leq 0,1)$ (табл. 4), что соответствует концу протокатагенеза и началу мезокатагенеза (градация $\mathrm{MK}_{1}{ }^{1}$ ) $[5,30]$, по остальным ароматическим параметрам оценка катагенетической преобразованности в основном получается завышенной, возможно, из-за низких концентраций ароматической фракции.

Таблица 3. Характеристики ациклических углеводородов-биомаркеров

Table 3. Characteristics of acyclic biomarker hydrocarbons

\begin{tabular}{|c|c|c|c|c|c|c|c|c|c|}
\hline & & & & & & & \\
\hline
\end{tabular}

$\mathrm{CPI}=\left[n \mathrm{C}_{23}+2\left(n \mathrm{C}_{25}+n \mathrm{C}_{27}+n \mathrm{C}_{29}+n \mathrm{C}_{31}\right)+n \mathrm{C}_{33}\right] / 2 /$

$/\left(n \mathrm{C}_{24}+n \mathrm{C}_{26}+n \mathrm{C}_{28}+n \mathrm{C}_{30}+n \mathrm{C}_{32}\right)$.

Paq $=\left(n \mathrm{C}_{23}+n \mathrm{C}_{25}\right) /\left(n \mathrm{C}_{23}+n \mathrm{C}_{25}+n \mathrm{C}_{29}+n \mathrm{C}_{31}\right)$.

В образцах обнаружен биомаркер хвойных растений ретен [6 и др.], отчетливо определяемый по $\mathrm{m} / \mathrm{z}$ 219, 234 [31]. Концентрации его увеличиваются вниз по разрезу и наибольшие обнаружены в образцах 1719 (рис. 6), где на хроматограммах общего тока они образуют абсолютный максимум. Другие высокие пики на хроматограмме ароматических соединений (рис. 6) определить не удалось, возможно, пик 1, судя по масс-фрагментограммам по m/z 141, 142 содержит длинноцепочечные алкилнафталины, источником которых являются водоросли Botryococcus Braunii, характерные для озерных обитателей [6 и др.], а пик 2, проявляющийся на масс-фрагментограмме по m/z 253, относится к моноароматическим соединениям. 

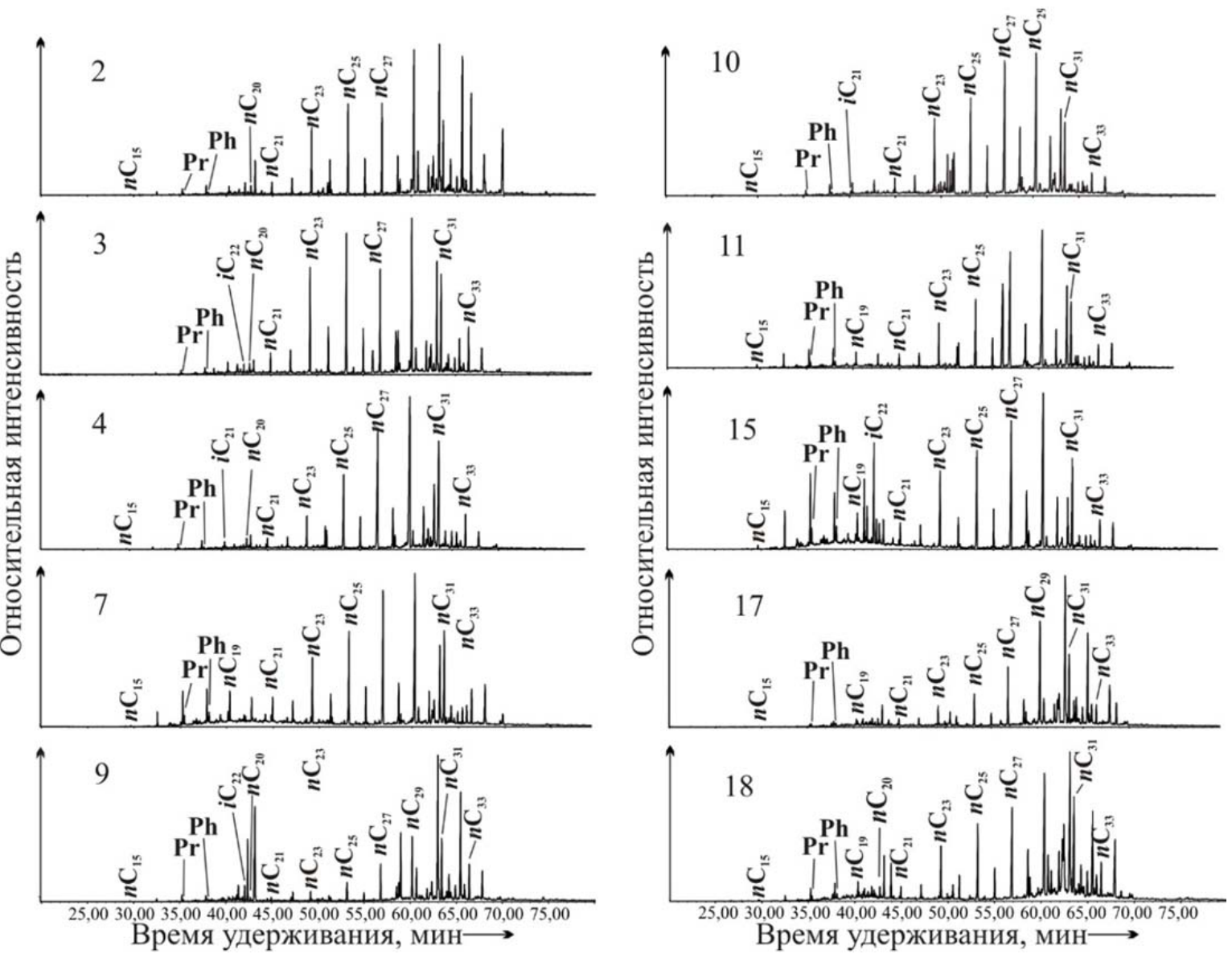

Pис. 3. Основные газожидкостные хроматограммы $\left(n C_{15+}-\right.$ н-алканы, $\operatorname{Pr}$ и $P h-$ пристан и фитан, $i C_{21}$ и $i C_{22}-$ ачиклические изопреноиды), номера образиов соответствуют табл. 3

Fig. 3. Main gas-liquid chromatograms $\left(n C_{15+}-n\right.$-alkanes, $\operatorname{Pr}$ and $P h-$ pristane and phytane, $i C_{21}$ and $i C_{22}-a c y c l i c$ isoprenoids); the sample numbers correspond to Table 3

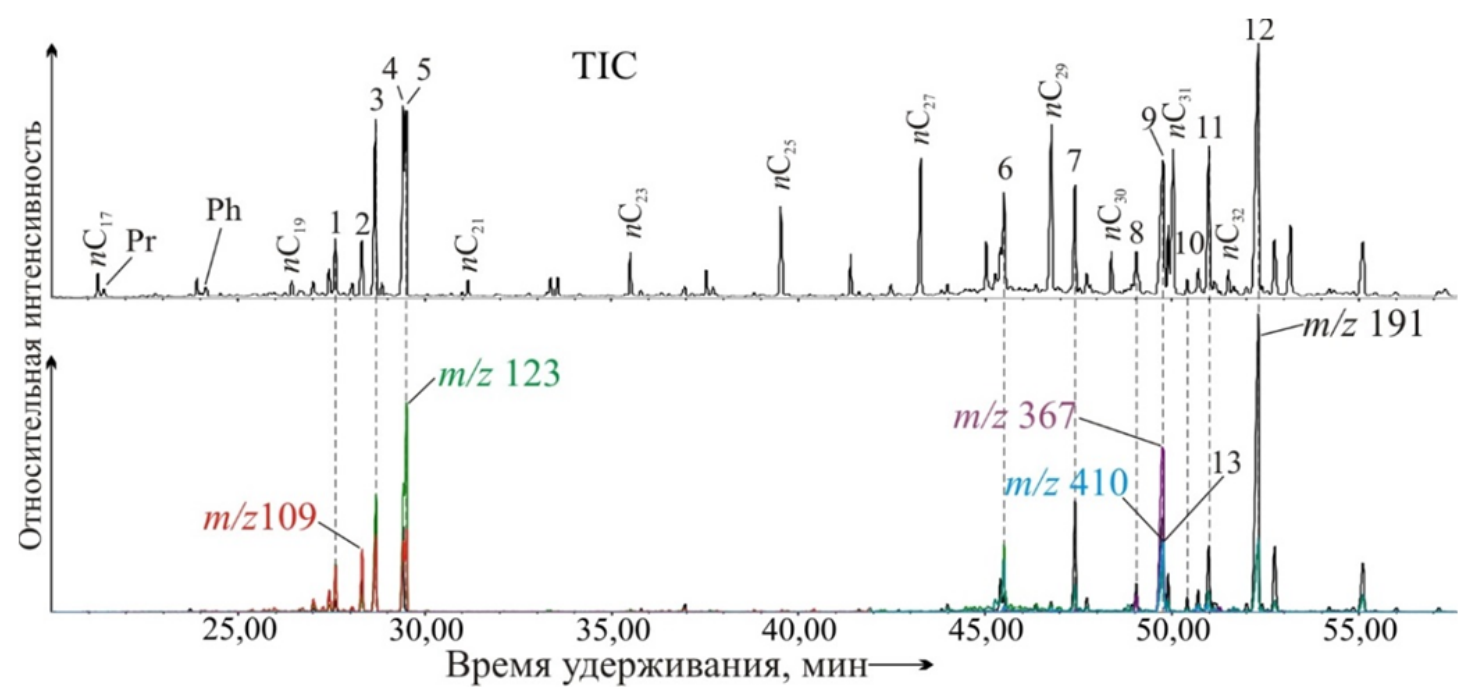

Рис. 4. Масс-хроматограмма по общему ионному току (TIC) и масс-хроматограммы терпановых углеводородов по ионам m/z 191, 123, 109, 367, 410, 193 из битумоида угля № 9 чернореченской свиты $\left(n C_{17+}-\right.$ н-алканы, $\operatorname{Pr} и$ Ph - пристан и фитан, 1 -бейеран, 2 - изопимаран, 3 - $\beta$-филлокладан, 4 - $\beta$-кауран, 5 - $\alpha$-филлокладан, 6 гопен 17(21) $C_{27}, 7$ - $\beta \beta$-гопан $C_{27}, 8$ - гопен $C_{30}$ ?, 9 - гопен 17(21) $C_{30}, 10-\alpha \beta$-гопан $C_{30}, 11$-моретан $C_{30}+\beta \beta$ гопан $C_{29}, 12-\alpha \beta$-гопан $C_{31} R+\beta \beta$-гопан $C_{30}, 13$ - олеанен?)

Fig. 4. Mass chromatogram by total ion current (TIC) and mass chromatograms of terpane hydrocarbons by ions $\mathrm{m} / z$ 191, 123, 109, 367, 410, 193 in the coal bitumen extract from sample no. 9 of the Black River Fm $\left(n C_{17+}-n\right.$-alkanes, $P r$ and $\mathrm{Ph}$ - pristane and phytane, 1 - beyerane, 2 - isopimarane, 3 - $\beta$-phyllocladane, 4 - $\beta$-kaurane, 5 $\alpha$-phyllocladane, 6 - hopene 17 (21) $C_{27}, 7-\beta \beta$-hopane $C_{27}, 8$ - hopene $C_{30}$ ?, 9 - hopene 17 (21) $C_{30}, 10-\alpha \beta$ hopane $C_{30}, 11$ - moretane $C_{30}+\beta \beta$-hopane $C_{29}, 12-\alpha \beta$-hopane $C_{31} R+\beta \beta$-hopane $C_{30}, 13$-oleanene?) 


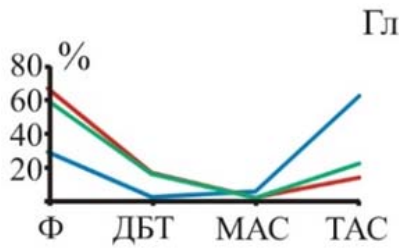

Глины ушумунской свиты (N, $\left.{ }^{\prime}{ }^{2}\right)$ ), скв.1138
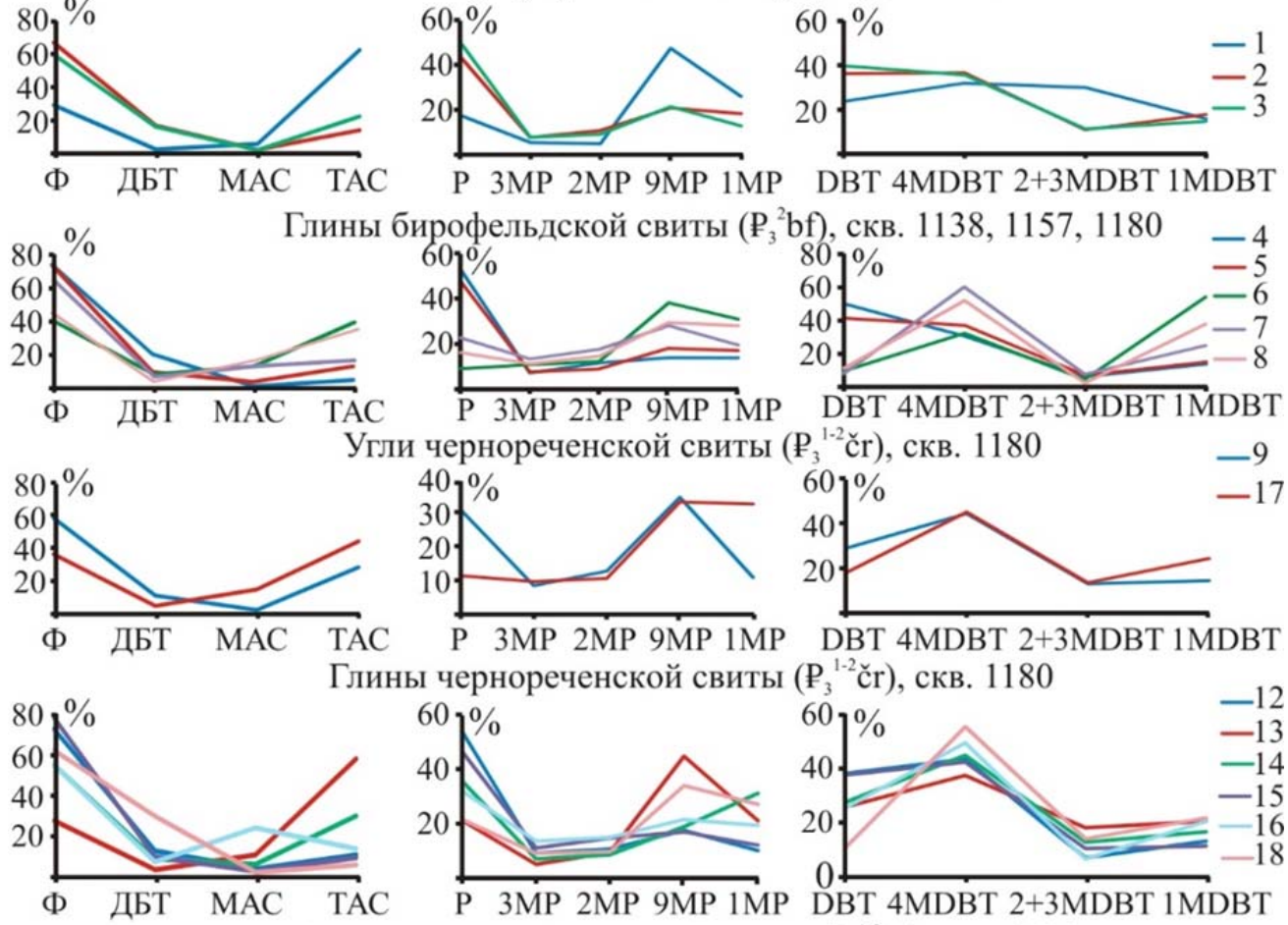

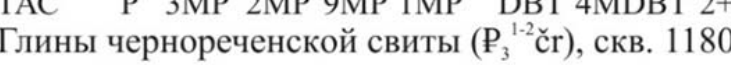
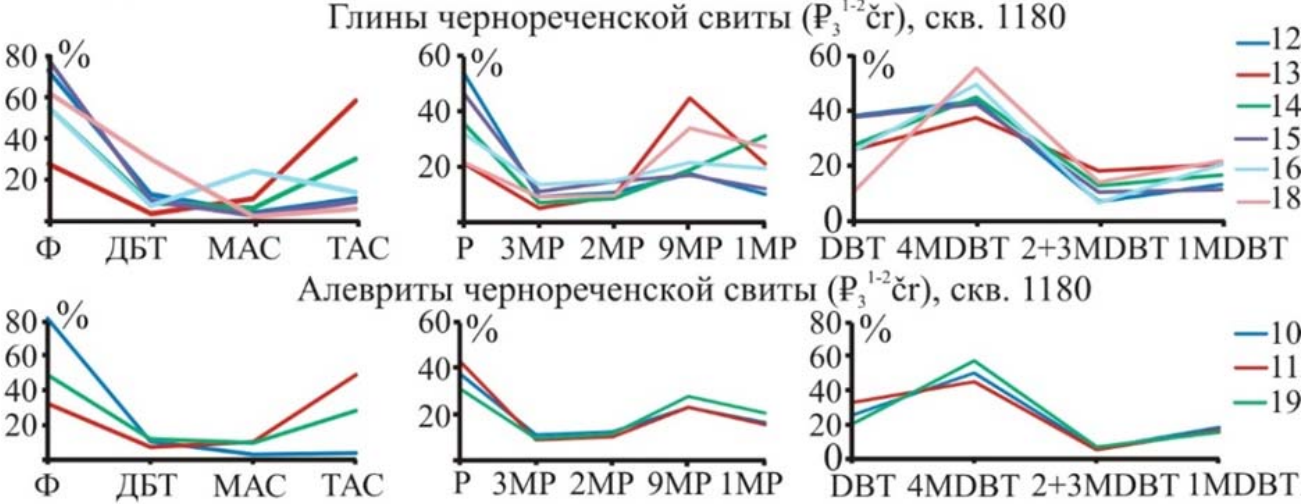

Рис. 5. Концентрачии ароматических и серосодержащих соединений (Ф - фенантрены, ДБТ - дибензотиофены, МАС и ТАС - моно- и триароматические стероиды), распределение фенантренов ( $P$ - фенантрен; $1 M P$, $2 M P, 3 M P, 9 M P-1-$, 2-, 3-, 9-метилфенантрены) и дибензотиофенов (DBT - дибензотиофен; 1MDBT, 2+3MDBT, 4MDBT-1-, 2- и 3-, 4-метилдибензотиофены), номера проб соответствуют табл. 4

Fig. 5. Concentrations of aromatic and sulfur-containing compounds ( $P$ - phenanthrenes, DBT-dibenzothiophenes, MAS and TAS - mono- and triaromatic steroids), distribution of phenanthrenes ( $P$ - phenanthrene; $1 M P, 2 M P, 3 M P$, 9MP-1-, 2-, 3-, 9-methylphenanthrenes) and dibenzothiophenes (DBT-dibenzothiophene; 1MDBT, 2+3MDBT, $4 M D B T-1-, 2+3-, 4-m e t h y l d i b e n z o t h i o p h e n e s)$, the sample numbers correspond to the Table 4

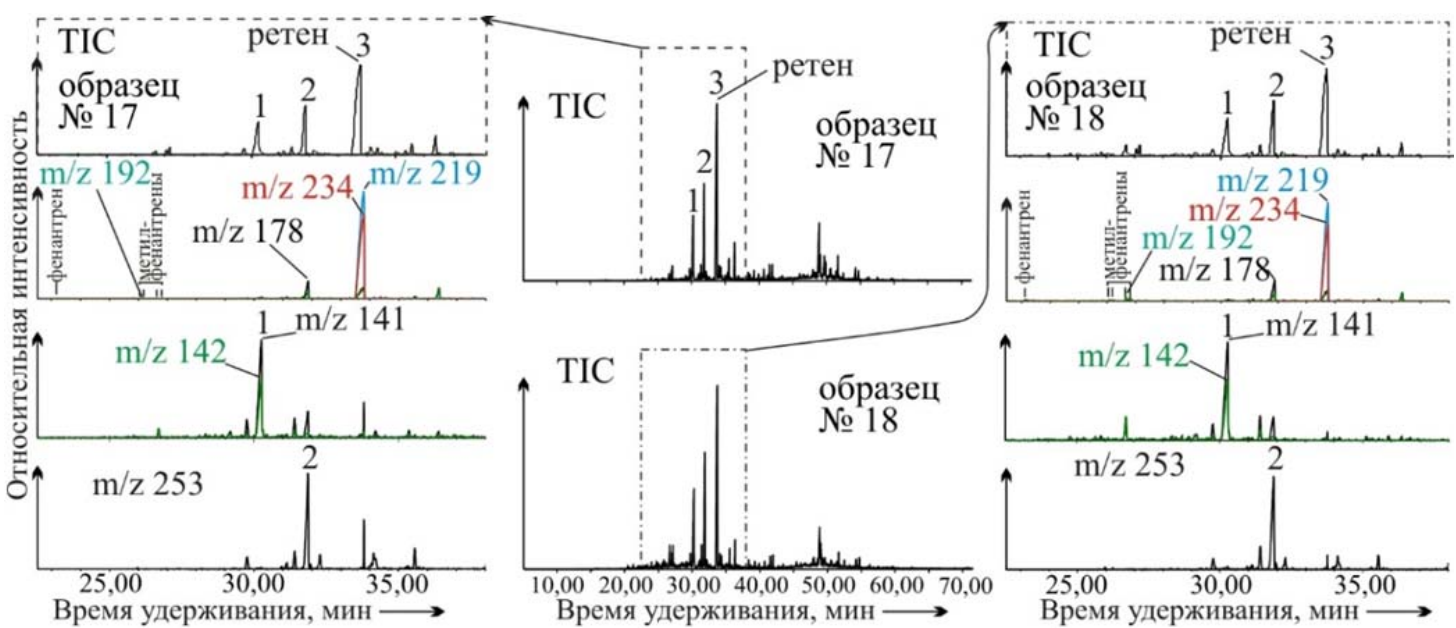

Pис. 6. Хроматограммы соединений ароматической фракиии по общему ионному току и синтетические массфрагментограммы (m/z 178, 192, 219, 234 и по 141, 142), а также масс-фрагментограмма моноароматических соединений (m/z 253) в образиах чернореченской свиты из скв. 1180 Уиумунского месторождения

Fig. 6. Chromatograms of compounds of aromatic fraction by TIC and synthetic mass fragmentograms (m/z 178, 192, 219, 234 and 141,142$)$, and a mass fragmentogram of monoaromatic compounds $(\mathrm{m} / z 253)$ in samples no. 17,18 from the Black River Fm, well 1180 of the Ushumunskoe field 
Таблица 4. Характеристики ароматических и серосодержаших соединений

Table 4. Characteristics of aromatic and sulfur-containing compounds

\begin{tabular}{|c|c|c|c|c|c|c|c|}
\hline 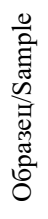 & 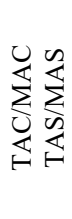 & 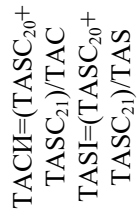 & 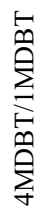 & 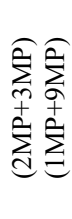 & 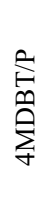 & 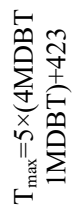 & 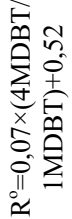 \\
\hline 1 & 11,1 & 0,01 & 2,0 & 0,1 & 0,2 & 433 & 0,66 \\
\hline 2 & 6,5 & 0,00 & 2,1 & 0,5 & 0,2 & 433 & 0,66 \\
\hline 3 & 12,3 & 0,00 & 2,4 & 0,5 & 0,2 & 435 & 0,69 \\
\hline 4 & 5,1 & 0,03 & 2,2 & 0,7 & 0,2 & 434 & 0,68 \\
\hline 5 & 3,5 & 0,01 & 2,5 & 0,5 & 0,1 & 435 & 0,69 \\
\hline 6 & 3,1 & 0,2 & 0,6 & 0,3 & 0,7 & 426 & 0,56 \\
\hline 7 & 1,3 & 0,1 & 2,4 & 0,7 & 0,3 & 435 & 0,69 \\
\hline 8 & 2,1 & 0,03 & 1,4 & 0,4 & 0,3 & 430 & 0,62 \\
\hline 9 & 12,6 & 0,1 & 3,1 & 0,5 & 0,3 & 439 & 0,74 \\
\hline 10 & 1,3 & 1,0 & 2,7 & 0,6 & 0,2 & 437 & 0,71 \\
\hline 11 & 4,8 & 0,02 & 2,7 & 0,5 & 0,2 & 437 & 0,71 \\
\hline 12 & 2,8 & 0,01 & 3,4 & 0,7 & 0,1 & 440 & 0,76 \\
\hline 13 & 5,5 & 0,05 & 1,8 & 0,2 & 0,2 & 432 & 0,65 \\
\hline 14 & 4,9 & 0,1 & 2,7 & 0,3 & 0,2 & 437 & 0,71 \\
\hline 15 & 3,6 & 0,01 & 3,8 & 0,9 & 0,1 & 442 & 0,79 \\
\hline 16 & 0,6 & 0,04 & 2,4 & 0,7 & 0,2 & 435 & 0,69 \\
\hline 17 & 3,0 & 0,02 & 1,9 & 0,3 & 0,5 & 432 & 0,65 \\
\hline 18 & 2,7 & 0,04 & 2,6 & 0,3 & 1,2 & 436 & 0,70 \\
\hline 19 & 2,9 & 0,03 & 3,7 & 0,4 & 0,5 & 441 & 0,78 \\
\hline
\end{tabular}

\section{Заключение}

Выполненные исследования позволяют определить следующие основные геохимические характеристики органического вещества Ушумунского месторождения:

- все изученные толщи содержат катагенетически незрелое (результаты углепетрографии, пиролиза) $\mathrm{OB}$;

- по изотопному составу углерода ОВ является террагенным, а по пиролитическим характеристикам в половине образцов - аквагенным;

- автохтонные (низкий битумоидный коэффициент $\beta$, низкие концентрации углеводородов) битумоиды являются по распределению н-алканов террагенными незрелыми (исходная биота представлена преимущественно древесными растениями, но с большим вкладом водных растений, имеющих надводную часть), по соотношение $\mathrm{Pr} / \mathrm{Ph}$

\section{СПИСОК ЛИТЕРАТУРЫ}

1. Среднеамурский осадочный бассейн: геологическое строение, геодинамика, топливно-энергетические ресурсы / отв. ред. Г.Л. Кириллова. - Владивосток: Дальневосточное отделение Российской академии наук, 2009. - 424 с.

2. Лопатин Н.В., Емец Т.П. Пиролиз в нефтегазовой геохимии. М.: Наука, 1987. - 144 c.

3. Меленевский В.Н. Методические рекомендации по применению пиролитических методов моделирования в органической геохимии: методическое рук-во. - Новосибирск: СНИИГГиМС, 1991. - 50 с.

4. Изотопный состав углерода рассеянного органического вещества и битумоидов и некоторые спорные вопросы теории образования нефти / А.Э. Конторович, Н.А. Верховская, И.Д. Тимошина, А.С. Фомичев // Геология и геофизика. 1986. - № 5. - C. 3-12. большей частью соответствуют аквагенному ОВ, и в ряде образцов максимумы в составе ациклических изопреноидов приходятся на $i-\mathrm{C}_{21}$ и $i-\mathrm{C}_{22}$, возможно, из-за значительного вклада организмов домена археа в исходное живое вещество;

- низкие концентрации или отсутствие стеранов и терпанов, присутствие биогопанов и гопенов характерно для незрелого ОВ;

- наличие каурана, биерана, филлокладанов также характерно для незрелого ОВ и свидетельствует об участии в комплексе исходного живого вещества смол высших растений Podocarpaceae и Araucareaceae;

- наличие биомаркера хвойных растений ретена и, возможно, присутствие длинноцепочечных алкилнафталинов, биомаркеров озерных водорослей Botryococcus Braunii указывают на основную флору, участвовавшую в исходном ОВ;

- в большинстве образцов характеристики ароматической фракции соответствуют аквагенному ОВ, пережившему диагенез часто с избытком серы в осадке;

- отношение триароматических стероидов ТАСИ соответствует концу протокатагенеза и началу мезокатагенеза (градация $\mathrm{MK}_{1}{ }^{1}$ ).

Возможно, особенности в характеристиках (террагенность по изотопному анализу, распределению $\mu$ алканов во всех образцах и по наличию биомаркеров высших наземных растений и аквагенность по пиролитическим данным, по ароматическим параметрам и ациклическим изопреноидам в большей части образцов) связаны с возрастной спецификой кайнозойского $\mathrm{OB}$ и с его катагенетической незрелостью при довольно высоких концентрациях, а также с неоднократными сменами режима осадконакопления изученных толщ Ушумунского месторождения с озерного до торфяно-болотного и обратно.

Авторы благодарят В.В. Крапивениеву за предоставление коллекиии пород Уиумунского месторождения для геохимических исследований и В.А. Каширчева за консультации по идентификации и интерпретации биомаркеров незрелого органического вещества.

Работа выполнена при поддержке проекта ФНИ № 0331-2019-0022 «Органическая геохимия и история геологического развития доминантных нефтегазовых систем верхнего протерозоя и фанерозоя Сибири».

5. Peters K.E., Moldowan J.M. The biomarker guide: interpreting molecular fossils in petroleum and ancient sediments. - New Jersey, Prentice Hall, Englwood Cliffs, 1993. - 363 p.

6. Peters K.E., Walters C.C., Moldowan J.M. The biomarker guide. Cambridge: Cambridge University Press, 2007. - 1155 p.

7. Фенантрены, ароматические стераны и дибензотиофены в юрских отложениях Западно-Сибирского нефтегазоносного бассейна и их значение для органической геохимии / А.Э. Конторович, В.Н. Меленевский, Е.Н. Иванова, А.Н. Фомин // Геология и геофизика. - 2004. - Т. 45. - № 7. - С. 873-883.

8. Radke M., Welte D.H., Willsch H. Maturity parameters based on aromatic hydrocarbons: Influens of the organic matter type // Organic Geochemistry. - 1986. - V. 10. - P. 51-63.

9. Aromatic components of coal: relation of distribution pattern to rank / M. Radke, H. Willsch, D. Leuthaeuser, M. Teichmuller // Geochimica et Cosmochimica Acta. - 1982. - V. 46. - P. 1831-1848. 
10. Schou L., Myhr M.B. Sulfur aromatic compounds as maturity parameters // Organic Geochemistry. - 1988. - V. 13. - P. 61-66.

11. Geochemical characteristics of Tertiary oils derived from siliceous sources in Japan, Russia and USA / A. Chakhmakhchev, M. Suzuki, A. Waseda, K. Takayama // Organic Geochemistry. 1997. - V. 27. - № 7-8. - P. 523-536.

12. Дахнова М.В. Геохимия сераорганических соединений и ее роль в прогнозе нефтегазоносности. - М.: Геоинформмарк, Геоинформ, 2000. $-50 \mathrm{c}$

13. Конторович А.Э., Парфенова Т.М., Иванова Е.Н. Ароматические углеводороды-биомаркеры и дибензотиофены в битумоидах куонамской свиты (северо-восток Сибирской платформы) // Доклады Академии Наук. - 2005. - Т. 402. - № 6. C. 804-806.

14. Coal characteristics and biomarker investigations of Dombayova coals of Late Miocene-Pliocene age (Afyonkarahisar-Turkey) / A. Bechtel, A.I. Karayigit, Y. Bulut, M. Mastalerz, R.F. Sachsenhofer // Organic Geochemistry. - 2016. - V. 94. P. 52-67.

15. Каширцев В.А., Конторович А.Э., Москвин В.И. Биомаркеры в органическом веществе палеогеновых отложений юга Западной Сибири (Омское Прииртышье) // Нефтехимия. 2008. - T. 48. - C. 269-276

16. Терпановые и стерановые углеводороды в углях различных генетических типов Сибири / В.А. Каширцев, В.И. Москвин, А.Н. Фомин, О.Н. Чалая // Геология и геофизика. - 2010. T. 51. - № 4. - C. 516-524.

17. Геохимия биомаркеров и катагенез органического вещества меловых и кайнозойских отложений Индигиро-Зырянского прогиба / В.А. Каширцев, В.В. Гайдук, О.Н. Чалая, И.Н. Зуева // Геология и геофизика. - 2012. - Т. 53. - № 8. - С. 1027-1039.

18. Characterisation of lignite lithotypes from the «Kovin» deposit (Serbia) - implications from petrographic, biomarker and isotopic analysis / D. Mitrović, N. Doković, D. Životić, A. Bechtel, O. Cvetković, K. Stojanović // Journal of the Serbian Chemical Society. - 2017. - V. 82. - № 6. - P. 739-754.

19. Современные методы анализа в органической геохимии / под ред. А.Э. Конторовича. - Новосибирск: Сибирский научноисследовательский институт геологии, геофизики и минерального сырья, 1973. - 100 с.

20. Matthews D.E., Hayes J.M. Isotope-ratio-monitoring gas chromatography-mass spectrometry // Analytical Chemistry. 1978. - V. 50. - № 11. - P. 1465-1473.

21. Werner R.A., Brand W.A. Referencing strategies and techniques in stable isotope ratio analysis. // Rapid Communications in Mass Spectrometry. - 2001. - V. 15. - № 7. - P. 501-519.
22. Чалая О.Н., Каширцев В.А. Основы хроматографии. - Якутск: Якутский государственный университет, 1997. - 156 с.

23. Organic geochemistry of the coal-bearing strata of the Ushumunskoe field (Khabarovsk territory) / V.V. Krapiventseva, I.D. Timoshina, A.N. Fomin, V.N. Melenevsky // The 28th International meeting on organic geochemistry. - Florence, Italy, 17-22 September 2017. URL: http://imog2017.org/wpcontent/uploads/2017/04/130.pdf (дата обращения 20.12.2019).

24. Тимошина И.Д. Органическая геохимия палеогеновых и неогеновых пород Ушумунского месторождения Среднеамурского осадочного бассейна // Новые идеи в геологии нефти и газа: Международная научно-практическая конференция. - М., 23-24 мая. - М., Московский государственный университет, 2019. - C. 474-475.

25. Тиссо Б., Вельте Д. Образование и распространение нефти. М.: Мир, 1981. -502 c.

26. Organic geochemistry of the Devonian bituminous shales and liptobiolithe coals of the Kuznetsk basin / A.E. Kontorovich, I.D. Timoshina, A.N. Fomin, V.N. Melenevsky // The 28th International meeting on organic geochemistry. - Florence, Italy, 17-22 September 2017. URL: http://imog2017.org/wpcontent/uploads/2017/04/157.pdf (дата обращения 20.12.2019).

27. Affouri H., Sahraoui. The sedimentary organic matter from a Lake Ichkeul core (far northern Tunisia): Rock-Eval and biomarker approach // Journal of African Earth Sciences. - 2017. - V. 129. P. 248-259.

28. Ficken K.J., Li B., Swain D.L., Eglinton G. An n-alkane proxy for the sedimentary input of submerged/floating freshwater aquatic macrophytes // Organic geochemistry. - 2000. - V. 31. - P. 745-749.

29. Tetracyclic diterpenoid hydrocarbons in some Australian coals, sediments and crude oils / R.A. Noble, R. Alexander, R.I. Kagi, J. Knox // Geochimica et Cosmochimica Acta. - 1985. - V. 49. P. 2141-2147.

30. Чахмахчев В.А., Карцев А.А., Прасолов Э.М. Геохимические показатели биогенной природы нафтидов // Геология нефти и газа. - 2005. - № 1.- С. 47-52.

31. Биомаркеры-фенантрены в органическом веществе докембрийских и фанерозойских отложений и в нефтях Сибирской платформы / В.А. Каширцев, Т.М. Парфенова, А.К. Головко, Б.Л. Никитенко, И.Н. Зуева, О.Н. Чалая // Геология и геофизика. - 2018. - Т. 59. - № 10. - С. 1720-1729.

Поступила 20.09.2019 г.

\section{Информация об авторах}

Тимошина И.Д., кандидат геолого-минералогических наук, старший научный сотрудник лаборатории геохимии нефти и газа Института нефтегазовой геологии и геофизики СО РАН.

Фомин $\boldsymbol{A . H . , ~ д о к т о р ~ г е о л о г о - м и н е р а л о г и ч е с к и х ~ н а у к , ~ г л а в н ы и ̆ ~ н а у ч н ы и ̆ ~ с о т р у д н и к ~ л а б о р а т о р и и ~ г е о х и м и и ~}$ нефти и газа Института нефтегазовой геологии и геофизики СО РАН; заведующий кафедрой геологии месторождений нефти и газа Геолого-геофизического факультета Новосибирского Государственного Университета. 
UDC 550.47:552.57(571.62)

\title{
ORGANIC GEOCHEMISTRY OF CENOZOIC ROCKS IN THE USHUMUNSKOE BROWN COAL FIELD OF THE MIDDLE AMUR SEDIMENTARY BASIN
}

Irina D. Timoshina1,

TimoshinalD@ipgg.sbras.ru

\author{
Alexander N. Fomin ${ }^{1,2}$, \\ FominAN@ipgg.sbras.ru, a.fomin@g.nsu.ru \\ 1 Trofimuk Institute of Petroleum Geology and Geophysics SB RAS, \\ 3, Academician Koptyug avenue, Novosibirsk, 630090, Russia. \\ 2 Novosibirsk State University, \\ 1, Pirogov street, Novosibirsk, 630090, Russia.
}

The relevance of the research is conditioned by the necessity to expand the resource base of the Russian Far East. The study of sedimentary basins and their hydrocarbon potential, the development of new forecast technologies for traditional and unconventional hydrocarbon fields is a priority for the Russian Academy of Sciences for many years. The evaluation of source rocks based on levels of their enrichment with the organic matter and its generation potential will provide valuable data for basin modeling. Besides, given that the Ushumunskoe source rocks have not been studied by organic geochemical methods, the present study sets out to clarify the conditions of the organic matter accumulation, and to reconstruct landscapes and biota in the Cenozoic Era.

The aim of the research is to characterize the biological source of the organic matter, conditions of its accumulation, diagenetic settings and the level of the Ushumunskoe source rocks maturity.

Objects of the research are the Ushumunskoe coals, clays and siltstones from the Middle Amur sedimentary basin.

Methods: comparison of the results of pyrolysis and isotope analysis of the organic matter and characteristics of biomarker hydrocarbons obtained using chromatography-mass spectrometry in saturated and aromatic fractions of bitumen extracts, evaluation of sources, as well as diagenetic and catagenetic conditions of organic matter.

Results. The Paleogene-Neogene source rocks of the Ushumunskoe brown coal field in the Middle Amur sedimentary basin were studied by the methods of organic geochemistry for the first time. The organic matter of the studied samples has signs of both terrestrial and sapropelic types. The organic carbon isotopic composition, $n$-alkanes distribution, the presence of kaurane, beyerane, phyllocladanes (biomarkers of higher plants Podocarpaceae and Araucareaceae) in the saturated fraction of extractable bitumens, retene (biomarker of conifers) in the aromatic fraction indicate the terrestrial (humic) nature of organic matter. At the same time, in most samples the aromatic fraction characteristics correspond to the sapropelic organic matter, which is evidenced by low concentrations of phenanthrenes, high concentrations of mono- and triaromatic steroids, distributions of methyldibenzothiophenes, and probable presence of long-chain alkylnaphthalenes (biomarkers of lake algae Botryococcus braunii). Phytane concentrations are significantly higher, than pristane, and half of the samples according to the hydrogen index (HI) values belong to type II. Due to the absence of marine deposits in the study area, type II is probably a mixture of type I (lacustrine) and III (continental). Moreover, judging by the HI variations throughout the section, depositional environments changed repeatedly from lacustrine to peatbog and vice versa. In some samples, the maxima in the acyclic isoprenoids fall on $i-C_{21}$ and $i-C_{22}$, possibly due to the significant contribution of archea to the original living substance. According to the high concentrations of dibenzothiophenes, the organic matter underwent diagenesis with high content of hydrogen sulfide in sediment. Probably, the duality of signatures (terrestrial and sapropelic) is associated with the specificity of the initial biota in this basin and is characteristic of its age and/or geographical localization. The vitrinite reflectance data, pyrolytic characteristics, high carbon preference index in $n$-alkanes, the presence of biohopanes and hopenes, almost complete absence of typical steranes and terpanes, and distribution of triaromatic steroids are interpreted as indications of immature organic matter, with the latter potentially enhancing such a duality of characteristics.

\section{Key words:}

The Far East, Paleogene, Neogene, brown coal, pyrolysis, isotopes, biomarker hydrocarbons, genesis and catagenesis of organic matter.

The authors thank V.V. Krapiventseva for providing a collection of rocks from the Ushumunskoe field for geochemical research and V.A. Kashirtsev for consulting on the identification and interpretation of biomarkers in immature organic matter.

The research was supported by the FSR project no. 0331-2019-0022 «Organic geochemistry and history of geological development of dominant oil and gas systems of upper Proterozoic and Phanerozoic of Siberia».

\section{REFERENCES}

1. Sredneamurskiy osadochny basseyn: geologicheskoe stroyenie, geodinamika, toplivno-energeticheskie resursy [Middle Amur sedimentary basin: geological structure, geodynamics, fuel and energy resources]. Ed. by G.L. Kirillova. Vladivostok, Dalnevostochnoe otdelenie Rossiyskoy akademii nauk Publ., 2009. 424 p.

2. Lopatin N.V., Yemets T.P. Piroliz v neftegazovoy geokhimii [Pyrolysis in oil and gas geochemistry]. Moscow, Nauka Publ., 1987. $144 \mathrm{p}$.
3. Melenevskiy V.N. Metodicheskie rekomendatsii po primeneniyu piroliticheskikh metodov modelirovaniya $v$ organicheskoy geokhimii: metodicheskoye rukovodstvo [Guidelines for the use of pyrolytic modeling methods in organic geochemistry: methodological guide]. Novosibirsk, SNIIGGiMS Publ., 1991. 50 p.

4. Kontorovich A.E., Verkhovskaya N.A., Timoshina I.D., Fomichev A.S. Izotopny sostav ugleroda rasseyannogo organicheskogo veshchestva i bitumoidov i nekotorye spornye voprosy teorii obrazovaniya nefti [The carbon isotopic composition of dispersed organic matter and bitumoids and some controversial issues in the theory of oil formation]. Geologiya i geofizika, 1986, no. 5, pp. 3-12. 
5. Peters K.E., Moldowan J.M. The biomarker guide: interpreting molecular fossils in petroleum and ancient sediments. New Jersey, Prentice Hall, Englwood Cliffs, 1993. 363 p.

6. Peters K.E., Walters C.C., Moldowan J.M. The biomarker guide Cambridge, Cambridge University Press, 2007. 1155 p.

7. Kontorovich A.E., Melenevskiy V.N., Ivanova E.N., Fomin A.N. Fenantreny, aromaticheskie sterany i dibenzotiofeny v yurskikh otlozheniyakh Zapadno-Sibirskogo neftegazonosnogo basseyna i ikh znachenie dlya organicheskoy geokhimii [Phenanthrenes, aromatic steranes and dibenzothiophenes in the Jurassic deposits of the West Siberian oil and gas basin and their importance for organic geochemistry]. Geologiya i geofizika, 2004, vol. 45, no. 7, pp. 873-883.

8. Radke M., Welte D.H., Willsch H. Maturity parameters based on aromatic hydrocarbons: Influens of the organic matter type. Organic Geochemistry, 1986, vol. 10, pp. 51-63.

9. Radke M., Willsch H., Leuthaeuser D., Teichmuller M. Aromatic components of coal: relation of distribution pattern to rank. Geochimica et Cosmochimica Acta, 1982, vol. 46, pp. 1831-1848.

10. Schou L., Myhr M.B. Sulfur aromatic compounds as maturity parameters. Organic Geochemistry, 1988, vol. 13, pp. 61-66.

11. Chakhmakhchev A., Suzuki M., Waseda A., Takayama K. Geochemical characteristics of Tertiary oils derived from siliceous sources in Japan, Russia and USA. Organic Geochemistry, 1997, vol. 27, no. 7-8, pp. 523-536.

12. Dakhnova M.V. Geokhimiya seraorganicheskikh soedineniy i ee rol v prognoze neftegazonosnosti [The geochemistry of organosulfur compounds and its role in the prediction of oil and gas]. Moscow, Geoinformmark, Geoinform Publ., 2000. 50 p.

13. Kontorovich A.E., Parfenova T.M., Ivanova E.N. Aromaticheskie uglevodorody-biomarkery i dibenzotiofeny $\mathrm{v}$ bitumoidakh kuonamskoy svity (severo-vostok Sibirskoy platformy) [Aromatic biomarker hydrocarbons and dibenzothiophenes in the bitumoids of the Kuonam Formation (northeast of the Siberian Platform)] Doklady Akademii Nauk, 2005, vol. 402, no. 6, p. 804-806.

14. Bechtel A., Karayigit A.I., Bulut Y., Mastalerz M., Sachsenhofer R.F. Coal characteristics and biomarker investigations of Dombayova coals of Late Miocene-Pliocene age (AfyonkarahisarTurkey). Organic Geochemistry, 2016. vol. 94, pp. 52-67.

15. Kashirtsev V.A., Kontorovich A.E., Moskvin V.I. Biomarkery v organicheskom veshchestve paleogenovykh otlozheniy yuga $\mathrm{Za}-$ padnoy Sibiri (Omskoe Priirtyshye) [Biomarkers in the organic matter of the Paleogene deposits of the south of Western Siberia (Omsk Irtysh)]. Neftekhimiya, 2008, vol. 48, pp. 269-276.

16. Kashirtsev V.A., Moskvin V.I., Fomin A.N., Chalaya O.N. Terpanic and steranic hydrocarbons in coals of various genetic types of Siberia. Russian Geology and Geophysics, 2010, vol. 51, no. 4 pp. 516-524. In Rus.

17. Kashirtsev V.A., Gayduk V.V., Chalaya O.N., Zueva I.N. Geochemistry of biomarkers and catagenesis of organic matter of the Cretaceous and Cenozoic deposits of the Indigiro-Zyryansk trough. Russian Geology and Geophysics, 2012, vol. 53, no. 8, pp. 1027-1039. In Rus.

18. Mitrović D., Doković N., Životić D., Bechtel A., Cvetković O., Stojanović K. Characterisation of lignite lithotypes from the «Kovin» deposit (Serbia) - implications from petrographic, biomarker and isotopic analysis. Journal of the Serbian Chemical Society, 2017, vol. 82, no. 6, pp. 739-754

19. Sovremennye metody analiza v organicheskoy geokhimii [Modern methods of analysis in organic geochemistry]. Ed. by A.E. Kontorovich. Novosibirsk, Siberian research institute of geology, geophysics and minerals Publ., 1973. $100 \mathrm{p}$.

20. Matthews D.E., Hayes J.M. Isotope-ratio-monitoring gas chromatography-mass spectrometry. Analytical Chemistry, 1978, vol. 50, no. 11, pp. 1465-1473.

21. Werner R.A., Brand W.A. Referencing strategies and techniques in stable isotope ratio analysis. Rapid Communications in Mass Spectrometry, 2001. vol. 15, no.7, pp. 501-519.

22. Chalaya O.N., Kashirtsev V.A. Osnovy khromatografii [The basics of chromatography]. Yakutsk, Yakutsk State University Publ., 1997. $156 \mathrm{p}$.

23. Krapiventseva V.V., Timoshina I.D., Fomin A.N., Melenevsky V.N. Organic geochemistry of the coal-bearing strata of the Ushumunskoe field (Khabarovsk territory). The $28^{\text {th }}$ International meeting on organic geochemistry. Florence, Italy, 17-22 September 2017. Available at: http://imog2017.org/wpcontent/uploads/2017/04/130.pdf (accessed 20 December 2019)

24. Timoshina I.D. Organicheskaya geokhimiya paleogenovykh i neogenovykh porod Ushumunskogo mestorozhdeniya Sredneamurskogo osadochnogo basseyna [Organic geochemistry of Paleogene and Neogene rocks of the Ushumunsky deposit of the Middle Amur sedimentary basin]. Mezhdunarodnaya nauchnoprakticheskaya konferentsiya. Novye idei $v$ geologii nefti $i$ gaza [New ideas in oil and gas geology]. Moscow, May 23-24, 2019. Moscow, Moscow State University Publ., 2019. pp. 474-475.

25. Tisso B., Velte D. Obrazovanie i rasprostranenie nefti [Oil formation and distribution]. Moscow, Mir Publ., 1981. 502 p.

26. Kontorovich A.E., Timoshina I.D., Fomin A.N., Melenevsky V.N. Organic geochemistry of the Devonian bituminous shales and liptobiolithe coals of the Kuznetsk basin. The $28^{\text {th }}$ International meeting on organic geochemistry. Florence, Italy, 17-22 September 2017. Available at: http://imog2017.org/wpcontent/uploads/2017/04/157.pdf (accessed 20 December 2019).

27. Affouri H., Sahraoui. The sedimentary organic matter from a Lake Ichkeul core (far northern Tunisia): Rock-Eval and biomarker approach. Journal of African Earth Sciences, 2017, vol. 129, pp. 248-259.

28. Ficken K.J., Li B., Swain D.L., Eglinton G. An n-alkane proxy for the sedimentary input of submerged/floating freshwater aquatic macrophytes. Organic Geochemistry, 2000, vol. 31, pp. 745-749.

29. Noble R.A., Alexander R., Kagi R.I., Knox J. Tetracyclic diterpenoid hydrocarbons in some Australian coals, sediments and crude oils. Geochimica et Cosmochimica Acta, 1985, vol.49, pp. 2141-2147.

30. Chakhmakhchev V.A., Kartsev A.A., Prasolov E.M. Geochemical indicators of the biogenic nature of naphthides. Oil and Gas Geology, 2005, no. 1, pp. 47-52. In Rus.

31. Kashirtsev V.A., Parfenova T.M., Golovko A.K., Nikitenko B.L., Zueva I.N., Chalaya O.N. Phenanthrene biomarkers in the organic matter of Precambrian and Phanerozoic deposits and in oils of the Siberian platform. Russian Geology and Geophysics, 2018, vol. 59, no. 10, pp. 1720-1729. In Rus.

Received: 20 September 2019.

\section{Information about the authors}

Irina D. Timoshina, Cand. Sc., senior researcher, Trofimuk Institute of Petroleum Geology and Geophysics SB RAS. Alexander N. Fomin, Dr. Sc., chief researcher, Trofimuk Institute of Petroleum Geology and Geophysics SB RAS; Head of Oil and Gas Field Geology Section, Novosibirsk State University. 